\title{
RECENT TECHNOLOGICAL DEVELOPMENTS IN PV+THERMAL TECHNOLOGY: A REVIEW
}

\author{
Supriya Sagar More ${ }^{1}$, G.Ravindranath ${ }^{2}$, Sagar Eknath More ${ }^{3}$ \\ ${ }^{I}$ Assistant Professor, Rajarambapu Institute of Technology, Sakharale \\ ${ }^{2}$ Principal, APS College of Engineering, Bangalore \\ ${ }^{3}$ Director-Technical, Utopia Automation \& Control, Satara
}

\begin{abstract}
Large amount of work had been carried out and going on in research and technological development of solar energy systems. Many systems have been innovated and approved as a product industrial bodies as per its market potential. Theoretical models have been developed, manufactured within specified design constraints and tested to get desired results. Many have optimized the systems using different advanced tools, some have developed software techniques like neural network, and the product developed is studied for market potential. The journey is going on in order to increase efficiency of system and compete with conventional energy prizes. This article gives an overview about the trend of solar technology development, future key areas in which researchers have to work for sustainable and efficient solar technology.
\end{abstract}

Keywords: - PV/T, solar energy, efficiency of PV cells, hybrid systems. $* * *$

\section{INTRODUCTION}

We , The Indians are blessed with all around the year good sunny days, we exactly knows the potential in solar energy, but there is no accelerated research and product development to make available this abundant source of energy to all of us with compatible prizes while at other hand the people from western countries are far more ahead of us in research and use of solar energy which contributes about $30 \%$ of their energy demands which makes them self dependant and hence contributing to make it a developed country.

Solar power is abundant source of energy the journey of currently available system is very huge and come up with various stage developments. The overall development can be measured in following stages

1. Photovoltaic cells without concentration.

2. Photovoltaic cells with concentration..

3. Hybrid $(\mathrm{PV}+\mathrm{T})$ system with concentration.

Development of efficient system must be main aim of researchers which comes from above stages but survey of needs and study of market potential is equally important in area of Solar Energy which can encourage people for it's use[10].

\section{SOLAR PHOTOVOLTAICS}

Alexandre Edmond Becquerel discovered the solar effect in1839 in which he stated that, "electrode kept in conductive solution produces electric current when shining light fall on the same". After a long time in 1941, Russell Ohl invented the solar cell. ENERGETICA INDIA - have published an article on, "How Solar is Transforming Rural India: Case Studies", in March 2014 in this article discussion have been made on use of solar energy for electricity its potential and income generation pattern in Indian villages, all energy based economical aspects which contributes rural development have been discussed here. Pradeep Chaturvedi,[11] 2005 President Indian Association for the Advancement of Science have mentioned views of Indian government for development of renewable energy sources and focus on research in solar photovoltaic's also development of product and its societal use in which he have given an example of largest solar cooking facility installed by the Tirumala Tirupathi Devasthanam (TTD) at Tirumala in Andhra Pradesh which can cook a food for 15,000 people/day. [MNRE].

\section{PHOTOVOLTAIC CELLS WITHOUT CONCENTRATION}

The main problem associated with solar cell is efficiency and cost of production of solar cell. As these to issues are related with material lot of research have been taken place and going on for advanced materials and advanced methods for production of solar cells.

Generally amorphous silicon solar cell is more popular on field. Satyen K. Deb[12] 2000 have worked on fabrication of gallium arsenide and its ternary alloys solar cell which get about $30 \%$ efficiency for a silicon-based solar cell based on single-crystal and polycrystalline silicon[8]. Material usage for silicon cells has been reduced significantly during the last 10 years from around $16 \mathrm{~g} / \mathrm{Wp}$ to $6 \mathrm{~g} / \mathrm{Wp}$ due to increased efficiencies and thinner wafers. We can again increase efficiency of solar cell by increasing solar energy quantum falling on the cell. As this issue has two considerations a) geographical location of site b) use of multi sun technology . As geographical location is 
uncontrolled phenomenon we can work on second option. A specially designed indirect thermosyphon solar water heater is designed and tested for its performance by KA Kui Tse[24] 2015, The design is combination of flat photovoltaic solar cells arrangement with specially designed circular tube ring type heat exchanger the heating of water in the rings is by themosyphon cycle. Another way by which we can increase PV concentration with decrease in demand of silicon is use of nano materials for PV cells. Mahesh Jadhav et al.[9],2010.gives study of dye sensitized solar cells with $\mathrm{TiO}_{2}$ as a mesoporous oxide layer which can be replaced by Zno. This research article supports solid state heterojunction dye solar cells which gives maximum efficiency with all visible radiation absorption capacity.

\section{PHOTOVOLTAIC SYSTEM WITH CONCENTRATION}

Multi sun Technology and concentration is more popular in thermal system as it increases solar gain. Almost all solar thermal plants are based on solar concentration technology However this seems to be failed in photovoltaic's as more the concentration more the energy dissipation more the surface temperature and lesser is the efficiency of solar cell.7 X low concentration system with compound parabolic concentrator have been designed Mark A Schuetz [18],2012.compound concentrator units are fabricated with thermofomic mirror grade acrylic material on syntactic foam mold protecting coating is applied for thermal durability and overall unit shows $86 \%$ overall efficiency of optical power reflectivity. Chengdong Kong \& ZilinXu et.al[3] 2013, derived performance of concentrated silicon solar cells by developing the model with Fresnel lense, flat mirrors and aluminium receiver to capture all incident radiations. Xinyue Han et al.[19] tried three concentration models with 57,47 and 37 sun and selected 37 concentration ratio model for further performance evaluation.

This issue opens the clue of solar photovoltaic cell cooling by different medias and the system gives photovoltaic as wel as thermal energy gain and hence improved performance of solar cell and increased efficiency of model. Cooling of photovoltaic cell had opened up the large area for research in solar energy.

Nanostructured silicon cells with thin film solar cells have been studied with model and Yun Da et. al.[13]2015 have been investigated that there negative coefficient of expansion which increases temperature and hence decreases rate of power conversion efficiency of these nano structured silicon cells, at temp $300 \mathrm{~K}$ to $400 \mathrm{~K}$. They have observed that as temperature of cell increases it alters the geometric properties of the cells . H. A. ZONDAG $\dagger$, et. AI[ 5]2002In this research work steady state as wel as dynamic models have been developed these PV and Thermal models have been simulated for cross verification of experimental work and the results are with $5 \%$ accuracy.
Vashi Sharma et al [22] 2015,Efficiency of solar collector depends on no. of factors. The system with linear Fresnel reflector for the factors which contributes decrease in efficiency for its optical performance is studied in this research work. The researchers found that unused portion of reflector aperture, inter row shading \& blocking, receivers transmitivity, absorptivity of absorber plate, cleanliness factor, covered portion of absorber etc.

The effect of all these parameters have been studied with mathematical modeling and numerical simulation have explored all the economic study and annual cost estimation the study gives better solutions in conclusion to optimize the losess.

\section{HYBRID $(\mathrm{PV}+\mathrm{T})$ SYSTEM WITH CONCENTRATION}

If we could catch maximum amount of energy receiving from sun we can increase efficiency of the system within same confined area (in yhe form of heat as wel as electricity.Cooling of PV cells can be possible with any liquid, air or water. Priit Pikk[7] In the this article an overview of possible solar cooling technologies is presented and a Comparison of roof top area needed is given

The hot air can be used for following application in decentralized manner.

1. Space heating

2. Grain dryer.

3. Paper mills.

4. Textile industries.

5. Process industries.

Advantages of using air for cooling of PV cells

1. Easily available, free of cost.

2. Leakage is not dangerous.

3. Inert fluid so no majaour reaction with any component material.

Hegazy[15]2000.Air as a heat collecting agent have been used to cool PV cells for which researcher have built three models first is with air flow above PV cell second is having air flow below PV cell and third one is with air flow on both the sides of PV cell. The performance of the cells is evaluated by taking into consideration fan power required to circulate air and they come to conclusion that the model with air flow on both sides of PV panel gives more power generation by keeping temperature of PV cells within acceptable range

The solar PV cell based space heating system with artificial neural network have been developed by Deepali Kamthania et.al .[17] 2011 at New Delhi with air as a working fluid between PV cell and heat exchanger unit. They have used MATLAB tool box for calculating overall efficiecy.The numerical simulation are compared with experimental model which shows $480.81 \mathrm{Kw} / \mathrm{hr}$ and $5^{\circ}-6^{0}$ increase in air temperature during winter. H. G. Teo, et al.[31]2012, cooled PV cells without concentration with 
active cooling i.e. by using forced convection with air as a working fluid and the researcher gets significant increase in efficiency over passive cooling technique.

\section{WATER AS COOLING MEDIA}

\subsection{Flow of Water around the PV}

Dr V. V. Devtore et al.[21] 2013. Have designed concentrated high photovoltaic module which contains PV cells at the centre to avoid melting of receiver, water have been circulated from the bottam which adds thermal energy gain to the efficiency of system. Analysis Of thermal and electrical performance of hybrid air based collector model have been developed and examined by Karima E. Amori et al.[ 2] 2012, in Iraq. Electrical, thermal and overall efficiency of panel increased up to check variable parameter performance and computer programming have been developed to solve mathematical model equations. This research work deals with single pass hybrid PV/T air collector is fabricated and modeled to determine thermal and electrical output. It is done for 11 case studies choosing different sites in Iraq. These models have been solved using MATLAB programming. In experimental results researchers get improved efficiency of model in summer as wel as in winter. Mathematical calculation have been carried out mathematically modeling of DWH system by Jose Tamayo et al[1] 2014.taking various performance parameters the results are optimized using evolutionary algorithm method. Hiren D. Raval et.al[23], Negative temperature coefficient causes increase in electrical energy gain with increase in temperature difference of PV cell and water. This research work have focused CFD analysis of PV cells under flow of water and results compared with experimentation are acceptable within $8 \%$ error.

\subsection{Submerged PV Cell}

Spectral response of $\mathrm{pV}$ immersed cells is presented by Jamal et.al[16]1992. Xinyue Han et al.[20] presented numerical analysis of liquid immersed PV cells to cool linear concentrating photovoltaic receiver, Experimental results are checked with modeling in CFD. Mathematical model is solved by using numerical approach . They comes at the conclusion that erosion and corrosion of parts have affected results which shows minor gap between experimental and numerical analysis result.The effect of depth of Immersion on performance of PV cell is evaluated by Sourabh Mehrotra et al.[ 25] They have found more efficiency at $1 \mathrm{~cm}$ depth. The performance at these depths increases due to absence of thermal drift and Low refractive index. Yiping Wang et. Al[27] taken trial on commercially available solar cell which gives increased efficiency which supports above work again.

\subsection{Cooling of Photovoltaic Cells with some Recent}

\section{Innovative Techniques}

A Hasan etal.[26] 2015, showed increase in performance of silicon polycrystalline photovoltaic panel by use of PCM to regulate temperature of photovoltaic cells. A specially designed aluminum container with back to back fins is used to increase convection rate from PV cells to PCM .They have used two proved PCM samples.

- $\quad$ Eutectic mixture of capric acid-palmitic acid

- $\mathrm{CaCl}_{2} 6 \mathrm{H}_{2} \mathrm{O}$

The research work shows very nice heat balance diagram with heat radiated convected and conducted out of incident energy on the specially designed container. The results for both the samples are taken at two sites one is in Ireland and second is in Pakistan. Obviously second site shows better results and economy due to its geographical position.

G. Zanganeh et al.[27] 2015, High temperature thermal energy $\left[575^{\circ} \mathrm{C}\right]$ storage unit for storage of latent as wel as sensible energy storage has been developed in this research work. Latent heat storage has been facilitated with use of $\left(\right.$ Alsi $\left.{ }_{12}\right)$ PCM and sensible heat storage by sedimentary rocks. The mathematical modeling $\&$ its validation with experimental results have been carried out. The system can be used for steam or gas turbine for energy production. Yanyang et al.[6] 2015, constructed silicon nitride microencapsulation to store solar thermal energy. The specially designed wrinkled surface and encapsulation design to adopt volume change of PCM during phase change enhances heat storing capacity. The PCM used here in this research work is polymethyl methacrylate based. This is advancement in previously mentioned research work.

\section{LIGHT WEIGHT TECHNOLOGY}

As the mass of system plays important role as energy consumption for tracking sun rays is more lesser is the efficiency of PV cells. So reduction in mass can be possible only with light weight materials for manufacturing of structure without compromising strength of the structure.

Dr. Ben Wang ,[28] 2013. In his research article have explained use of lightweight composite material in energy sector and various methods on manufacturing of these special application structure.

Atul A Sagade, Satish aher et al. [4 ]2013, In this research work there is use of solar reflector which is made up of fiberglass reinforced plastic which is coated with aluminium foil having reflectivity 0.86 . Observations of the experiment have been taken by using glass cover and without using glass cover at the end researchers comes with conclusion that FRP reduces capital cost and glass cover increases efficiency of the system by reducing convection loss.

\section{SOME APPLICATIONS OF HYBRID PV} SYSTEM

Marco Beccali et al [14], 2009 Dessican evaporative cooling system is analyzed here for its performance for air conditioning. The system is designed, fabricated and tested for its performance in summer as wel as in winter. The observations showed that the system seems to be proved with moderate efficiency for electricity production and not 
for cooling or heating applications. The performance of a building-integrated photovoltaic-thermal collector is examined by this project case study [26]. A collector assembly constructed from market-available products was tested at the University of Colorado at Boulder for several weeks during the spring of 2010 with the goal of creating an affordable, effective device. The collector is composed of a photovoltaic panel with a solar thermal pool heater adhered to the back, a configuration that was intended to maximize the contact area between the components. Rekha $\mathbf{L}$ et al[ 30] 2013, have worked on thermal hybrid solar system for residential application the study gives mathematical modeling and analysis of flat plate collector and enhancement in efficiency which is beneficial for thermal and electrical requirements of home. Huan-Liang Tsai,[29] 2014, designed and tested PV / $\mathrm{T}$ assisted heat pump water heating system the model is built in MATLAB for simulation and result gives better COP.

\section{CONCLUSION}

After extensive study of all research paper we come to conclusion that the development of PV/ $\mathrm{T}$ system is in progress which have been studied and experimented for all aspects its concentration, developing parallel performance material which can replace si demand and which will be promising source, cooling of PV cells with better media, making system light weight, developing some application based on these system. In Every research work mathematical models have been developed this theoretical models have been validated experimentally and also with the help of some modern tools like MATLAB for modeling, CFD to chek performance of water cooled or air cooled systems etc. Even though some extensive research is needed in this area in order to make more efficient system which can serve many application in the world which may be domestic or industrial, This research should support decentralized power units which serves the society for its power demand with less ROI period. The system should be made so simple so that the people in rural areas should be motivated to use without any hesitation. With this aim we are going to built our system in our upcoming research work.

\section{REFERENCES}

[1] Jose Tamayo Vera,Timo Laukkanen,2014, " Multiobjective optimization of hybrid photovoltaicthermal collectors integrated in a DWH heating system “. journal of Energy and Building 78-90.

[2] Karima E. Amori , Hussein M.Taqi Al-Najjar,2012, “ Analysis of thermal and electrical performance of a hybrid (PV / T) air based solar collector for Iraq." Journal of Applied Energy, 384-395.

[3] Chengdong Kong, Zilin Xu, 2013, "Outdoor performance of low concentrated photovoltaic thermal hybrid system with crystalline silicon solar cells", Journal of Applied Energy, 618-625.

[4] Atul A Sagade, Satish aher etl.2013,Performance Evaluation of low cost FRP parabolic trough reflector with mild steel receiver ", International Journal of Energy and Environmental Engineering , 4:5.
[5] H. A. ZONDAG, D. W. DE VRIES , "The Thermal And Electrical Yield Of A PV -Thermal Collector Solar Energy Vol. 72, No. 2, pp. 113-128, 20022 Elsevier Science Ltd.

[6] Yanyang Yang, Xiaoxin Ye, Jie Luo, Yuan Liu,Guoyi Tang, "polymethyl methacrylate based phase change microencapsulation for solar energy storage",Solar energy 115(2015)289-296.

[7] Priit Pikk, Andres Annuk "Overview of PhotovoltaicThermal Collector Cooling Technologies in Northern Latitudes "report for Estonian University of Life Sciences

[8] M.Vivar, J. Daniel, I.L.Skrybin,V.A. Everrett,A.W.Blakers,L.Suganthi,S.Iniyan, "A Hybrid Solar linear concentrator prototype in India", IEEE Photovoltaic Specialists Conference (PVSC 2010), ed. Institute of Electrical and Electronics Engineers (IEEE Inc), Piscataway USA, pp. 003092 - 003097.

[9] Mahesh Jadhav, A.S. Todkar, Vilas Gambhire,S.Y.Sawant, Nanotechnology for powerful solar energy", International Journal of Advanced Biotechnology and Research vol.2, issue 1,2011,pp 208-212

[10] T.T. Chow, “ A review on photovoltaic/thermal hybrid solar technology",Jornal of Applied Energy 87,pp365-379,2010.

[11] Pradeep Chaturvedi, "Renewable Energy in India Programmes and Case Studies", ISECSO, science and Technology Vison volume -May 2005( 61 - 64 )

[12] Satyen K. Deb 2000," Recent Developments in High Efficiency PV Cells ",the World Renewable Energy Congress VI Brighton, U.K. July 1-7, 2000.

[13] Yun da,Yimin Xuan, "Effect of temperature on performance of nanostructured silicon thin film solar cells",Solar Energy 115(2015)109-119

[14] M. Beccali, P. Finocchiaro, B.Nocke, "Energy and economic assessment of desiccant cooling system coupled with single glased air \& hybrid PV/T solar collector for application in hot \& humid climate Solar Energy- 83(10)828(2009).

[15] Hegazy, A.A. (2000). Comparative study of the performances of four photovoltaic/thermal solar air collectors. Energy Conversion and Management, vol. 41, p. 861-881, DOI:10.1016/S0196-8904(99)00136-

[16] Muadi , M. Jamal, "Spectral response and efficiency of silicon solar cells below water surface," Solar Energy, 49, 1992,pp29-33.

[17] Deepali kamathiya, G. N. Tiwari, "Determination of Efficiency of Hybrid Photovoltaic Thermal Air Collectors using Artificial Neural Network Approach for Different PV Technology" BIJIT - 2012; January - June, 2012; Vol. 4 No. 1; ISSN 0973 - 5658 397404.

[18] Mark A Schuetz, A. Shell, Scott A. Brown, Gregory S. Reinbolt, "Design and construction of a 7 X Low concentration photovoltaics system based on parabolic concentrators, Journal of Photovoltaics, IEE vol 2. No.3 July 2012. 
[19] Building - integrated photovoltaic / Thermal collector panel design and test report for university of colorado at Boulder :2010

[20] Xinyuen Han, Vernie Everett, Yiping Wang, Li Zhu, "Numerical Analysis of direct liquid immersed solar cell cooling of a linear concentrating photovoltaic receiver.

[21] V.V. Deotare ,D.V.Padole, S.K. Sawant, "High efficiency auto tracking solar combined heat and power generation system", Indian journal of applied Research vol.3 issue 7 (2013) 221

[22] Vashi Sharma, Jayanta K. Nayak, Shireesh B. Kedane, "Effects of Shading and Bloking in Linear Fresnel Reflector field, Solar Energy, 113 (2015) 114-138.

[23] Hiren Raval, Subarna Maiti, Ashish Mittal, "Computational fluid dynamics analysis and experimental validation of Improvement in Overall Energy efficiency of Solar Photovoltaic panel by thermal energy recovery.

[24] Ka - Kui Tse, Tin- Tai Chow, "Dynamic model and experimental validation of an Indirect thermosyphon solar water heater coupled with a parallel circular tube rings type heat exchanger coil, Solar Energy, 114 (2015) 114-133.

[25] Soubabh Mehrotra, Pratish Rawat, Mary Debbarma, K. Sudhakar, "Performance of A Solar panel with Water Immersion Cooling Technique", International Journal of Science, Environment and Technology, Vol. 3 2014, 1161-1172.

[26] A. Hasan, S.J. Mccormack, M. J. Huang, J. Sarwar, B. Nortan, "Increased photovoltaic pefomance through temperature regulation by phase change materials comparision in different climates, Solar Energy, 115 (2015) 264- 276.

[27] G. Zanganesh, R. Khanna, C. Walser, A. Pedretti, A. Haselbacher, A. Seinfeld, "Experimental and Numerical Investigation of combined sensible latent heat for thermal energy storage at $575^{\circ} \mathrm{C}$ and above, Solar Energy, 114 (2015) 77-90.

[28] Dr. Ben Wang, "Lightweight composite material and manufacturing",GTMI, point of view paper.

[29] Huan-Liang Tsai, "Design and evaluation of a photovoltaic/Thermal assisted heat pump water heating system", energies 2012 7,3319-3338.

[30] Rekha L, Vijayalakshmi M M, Natarajan E, "Photovoltaic thermal hybrid system for residential applications",International Journal of Research in Engineering vol 2,(277-280).

[31] H. G. Teo, P.S.Lee, M.N.A.Hawaldar, "An active cooling sytem for photovoltaic module", Applied Energy 90(2012) 309-315. 